\title{
PENGARUH BAHAN PENGISI ARANG TANDAN KOSONG KELAPA SAWIT TERHADAP SWELLING DAN KETAHANAN USANG KARET KOPLING KENDARAAN BERMOTOR RODA DUA
}

\author{
EFFECT OF EMPTY FRUIT BUNCHES OF PALM OIL CHARCOAL FILLER ON \\ SWELLING AND AGEING RESISTANCE OF CLUTCH RUBBER TWO WHEEL MOTOR \\ VEHICLE
}

\author{
Hari Adi Prasetya ${ }^{1^{*}}$ dan Popy Marlina ${ }^{1}$ \\ ${ }^{1}$ Balai Riset dan standardisasi Industri Palembang \\ Jalan Perindustrian II, KM.9 No.12, Sukarami, Palembang \\ *main contributor and corresponding author \\ email : hariadiprasetya@yahoo.co.id
}

Diterima: 22 April 2019; Direvisi : 19 Juli 2019 - 24 Juli 2019; Disetujui: 25 Juli 2019

\begin{abstract}
Abstrak
Karet kopling kendaraan bermotor roda dua dalam penggunaannya harus tahan terhadap kerusakan terutama minyak karena bekerja pada pelumas dengan temperatur yang tinggi. Penelitian ini bertujuan untuk mengetahui pengaruh arang Tanda Kosong Kelapa Sawit (TKKS) terhadap swelling dan ketahanan usang karet kopling kendaraan bermotor. Rancangan yang digunakan pada penelitian ini adalah Rancangan Acak Lengkap (RAL) dengan faktor perlakuan variasi konsentrasi arang TKKS, T1 $=0 \mathrm{phr}, \mathrm{T} 2=35 \mathrm{phr}$, T3 $=45$ phr, dan T4 = 55 phr, masing-masing perlakuan diulang 3 (tiga) kali. Selanjutnya masing-masing karet kopling di rendam pada oli mesin SAE $10 \mathrm{~W}$ - 40 , dengan temperatur oli bervariasi $25^{\circ} \mathrm{C}$ dan $100^{\circ} \mathrm{C}$ dan lama perendamam bervariasi $0,24,48,72,96$ dan 120 jam dan pengujian ketahanan usang dilakukan pada suhu $70^{\circ} \mathrm{C}$ selama 24 jam. Hasil penelitian menunjukkan bahwa semua perlakuan mempunyai pengaruh pada swelling dan ketahanan usang karet kopling. Ketahanan usang karet kopling untuk kekerasan, tegangan putus dan perpanjangan putus memenuhi persyaratan teknis karet kopling kendaraan bermotor roda dua komersil. Arang TKKS dapat digunakan sebagai bahan pengisi untuk produk karet dan dapat digunakan sebagai alternatif pengganti bahan pengisi komersial.
\end{abstract}

Kata kunci : Arang TKKS, Karet Kopling Kendaraan Bermotor Roda Dua, Ketahanan Usang, Swelling.

\section{Abstract}

Clutch rubber two wheel motor vehicle its use must be resistant to damage, especially oil because it works on lubricants with high temperatures. The study aims to determine the Effect of Empty Fruit Bunches of Palm Oil Charcoal Filler on Swelling and Ageing Resistance of Clutch Rubber Two Wheel Motor Vehicle. The design is Completely Randomized Design (RAL) factorial, each treatment repeated three times with treatment factors of charcoal concentration variation TKKS, T1 $=0 \mathrm{phr}, \mathrm{T} 2=35 \mathrm{phr}, \mathrm{T3}=45 \mathrm{phr}$, and T4 $=55 \mathrm{phr}$, Furthermore, each clutch rubber is immersed in SAE $10 \mathrm{~W}$-40 engine oil, with oil temperatures varying $25^{\circ} \mathrm{C}$ and $100^{\circ} \mathrm{C}$ and immersion times varying from 0, 24, 48, 72, 96 and 120 hours and ageing resistance test at $70^{\circ} \mathrm{C}$ for 24 hours

The results showed that all treatments had a effect on clutch rubber two wheel motor vehicle. The ageing resistance for hardness, tensile strength and elongation et break is fulfill of commercial that clutch rubber two wheel motor vehicle. TKKS charcoal can be used as a filler for the products of rubber and can be used as an alternative of commercial fillers.

Keywords : TKKS Charcoal, Clutch Rubber Two Wheel Motor Vehicle, Ageing Resistance, Swelling.

\section{PENDAHULUAN}

Karet merupakan salah satu jenis polimer yang memiliki nilai yang sangat baik dalam banyak aplikasi, seperti dibidang teknik, kesehatan, otomotif dan keperluan rumah tangga. Karet dalam keadaan mentah tidak cukup baik untuk diaplikasikan, maka diperlukan penambahan aditif untuk membantu memperbaiki sifat-sifat karet, sehingga bisa bermanfaat dan dapat diaplikasikan. Salah satu bahan aditif yang ditambahkan dalam karet yaitu bahan 
pengisi. Bahan pengisi yang umum digunakan adalah carbon black. Penelitian untuk mencari alternatif bahan pengisi yang berasal dari sumber daya alam, telah banyak dilakukan, pemanfaatan produk sampingan hasil pengolahan pertanian, seperti cangkang sawit (Prasetya, 2017; Daud, et al., 2016), sekam padi (Marlina et al., 2014; Vichitcholchai, 2012), memanfaatkan cangkang biji Cherry (Chrysophyllum albidum) (Osabohien and Egboh, 2007), penelitian arang tempurng kelapa (Vijayan et al., 2012).

Penelitian ini menggunakan arang tandan kosong kelapa sawit (TKKS), sebagai bahan pengisi alternatif dalam pembuatan karet kopling kendaraan bermotor roda dua. TKKS merupakan kumpulan serat yang tertinggal setelah memisahkan buah dari tandan buah segar yang telah disterilkan (dengan penguapan pada $294 \mathrm{kPa}$ selama 1 jam) (Shinoj et al., 2011). TKKS murah, dapat terdekomposisi, tidak beracun, dan merupakan serat alami yang digunakan secara luas. Tandan kosong kelapa sawit merupakan material alami yang mengandung filament yang tebal dan kasar (Al-Rahman et al., 2014). Hal tersebut membuat tandan kosong kelapa sawit lebih efektif dibandingkan material industri yang tidak dapat diperbaharui, berbahaya untuk kesehatan dan lingkungan, serta mahal untuk produksi skala kecil (Ismail et al., 2010). Senyawa yang paling banyak terkandung dalam serat tandan kosong kelapa sawit adalah holoselulosa, alpha selulosa, hemoselulosa dan lignin. Holoselulosa dan hemiselulosa memiliki struktur kimia yang sama dengan selulosa. Selulosa berfungsi untuk membentuk pori pada komposit. Pori-pori pada permukaan serat kelapa sawit memiliki rata-rata diameter sebesar 0,07 m. Morfologi permukaan pori ini sangat berguna untuk meningkatkan ikatan mekanik dengan resin matriks jika digunakan pada pembuatan komposit (Sung, et al., 2017). Karet kopling merupakan komponen penting dalam mesin kendaraan bermotor roda dua yang berfungsi untuk meredam hentakan pada saat mengalihkan tenaga mesin melalui transmisi untuk pengaturan kecepatan kendaraan. Di dalam rumah kopling terdapat pelumas untuk memperlancar gerak kopling dan bekerja pada temperatur yang cukup tinggi. Karet kopling sering mengalami kerusakan dan jika hal ini terjadi dalam waktu yang lama maka akan berdampak fatal terjadinya kerusakan pada rumah kopling yang membuatnya menjadi aus. Hal ini mengakibatkan mengurangi kinerja dari komponen lainnya yang terdapat pada instalasi kopling. Agar karet kopling yang digunakan dapat tahan terhadap kerusakan karena bekerja pada pelumas dengan temperatur yang tinggi, maka pada penelitian ini, karet kopling dibuat menggunakan filler yang berasal dari tandan kosong kelapa sawit (TKKS). Penelitian ini bertujuan untuk mengetahui pengaruh arang TKKS terhadap ketahanan usang dan swelling karet kopling kendaraan bermotor dalam pelumas.

\section{BAHAN DAN METODE}

\section{Bahan}

Standard Indonesian Rubber (SIR) 20, Nitro Butadiena Rubber (NBR), N330 (Carbon Black), 6PPD, ZnO, Asam Stearat, Trimethyl Quinon (TMQ), sulfur, Cyclohexyl-2-benzothiazylsulfenamide (CBS), Tetramethyl Thiuram Disulfide (TMTD), coupling agent Si69 dan arang tandan kosong kelapa sawit (TKKS).

\section{Alat}

Peralatan yang digunakan pada penelitian ini adalah gunting, cetakan (moulding) barang jadi karet kopling, open mill, alat press vulkanisasi, per keong mobil, crusher dan ayakan 400 mesh.

\section{Metode Penelitian Rancangan Percobaan}

Penelitian dilakukan dalam skala laboratorium menggunakan metode Rancangan Acak Lengkap (RAL) dengan faktor perlakuan variasi konsentrasi 
arang TKKS, $\mathrm{T}_{1}=0 \mathrm{phr}, \mathrm{T}_{2}=35 \mathrm{phr}, \mathrm{T}_{3}=$ $45 \mathrm{phr}$, dan $\mathrm{T}_{4}=55 \mathrm{phr}$, masing-masing perlakuan diulang 3 (tiga) kali. Formula karet kopling seperti pada Tabel 1.

Selanjutnya masing-masing karet kopling di rendam pada oli mesin SAE $10 \mathrm{~W}$ - 40, dengan temperatur oli bervariasi $25^{\circ} \mathrm{C}$ dan $100^{\circ} \mathrm{C}$ dan lama perendamam bervariasi $0,24,48,72,96$ dan 120 jam dan pengujian ketahanan usang dilakukan pada suhu $70^{\circ} \mathrm{C}$ selama 24 jam.

Tabel 1. Formula Karet Kopling

\begin{tabular}{lcccc}
\hline \multicolumn{1}{c}{ Formula } & \multicolumn{4}{c}{ Perlakuan (phr) } \\
& $\mathbf{T}_{\mathbf{1}}$ & $\mathbf{T}_{\mathbf{2}}$ & $\mathbf{T}_{\mathbf{3}}$ & $\mathbf{T}_{\mathbf{4}}$ \\
\hline SIR 20 & 80 & 80 & 80 & 80 \\
NBR & 20 & 20 & 20 & 20 \\
N330 (Carbon & 5 & 5 & 5 & 5 \\
black) & & & & \\
Arang TKKS & - & 35 & 45 & 55 \\
6PPD & 2 & 2 & 2 & 2 \\
TMQ & 1,5 & 1,5 & 1,5 & 1,5 \\
ZnO & 5 & 5 & 5 & 5 \\
Asam stearat & 2 & 2 & 2 & 2 \\
CBS & 1,5 & 1,5 & 1,5 & 1,5 \\
TMTD & 1,5 & 1,5 & 1,5 & 1,5 \\
Si69 & 1 & 1 & 1 & 1 \\
Sulfur & 2,5 & 2,5 & 2,5 & 2,5 \\
\hline
\end{tabular}

Tahapan Penelitian

Persiapan Bahan

Bahan yang digunakan untuk pembuatan kopling kendaraan bermotor roda dua sesuai dengan perlakuan pada formula yang telah ditentukan (Tabel 1). Masingmasing bahan ditimbang sesuai dengan dengan perlakuan yang ditentukan dengan ukuran phr (berat per seratus karet).

\section{Pencampuran dan Pencetakan}

Proses pencampuran dilakukan secara bertahap untuk setiap bahan. Pencampuran dilakukan dalam gilingan terbuka (open mill). Tahapan proses pencampuran adalah sebagai berikut :

Mastikasi karet alam SIR 20 selama 1-3 menit, dilanjutkan pencampuran elastomer dengan bahan kimia untuk pembuatan kompon karet, antara lain bahan pengisi arang TKKS, sambil digiling setiap sisi karet dipotong sampai dua atau tiga kali selama 3-8 menit. Selanjutnya bahan penggiat/activator, $\mathrm{ZnO}$ dan asam stearat ditambahkan, kembali dipotong setiap sisi kompon, pemotongan dilakukan satu sampai tiga kali selama 23 menit. Antioksidan TMQ dan 6PPD ditambahkan, dipotong setiap sisi kompon sampai 3 kali selama 2-3 menit. Accelerator TMTD dan CBS ditambahkan, setiap sisi kompon kembali dipotong dua atau tiga kali selama 1-3 menit. Coupling agent Si69 ditambah, sulfur (vulkanisator) ditambahkan pada kompon sampai homogen. Selanjutnya ditentukan ukuran ketebalan lembaran kompon dengan menyetel jarak roll pada cetakan sheet. Setelah mencapai ketebalan yang diinginkan, kompon dikeluarkan dari open mill dan diletakkan diatas plastik transfaran.

Kemudian dilakukan pencetakan karet kopling, kompon di vulkanisasi dengan cara dipress sesuai dengan ukuran sampel pada temperatur $145^{\circ} \mathrm{C}$ Setelah kompon karet mengalami vulkanisasi (thermoset rubber), karet tersebut dilepaskan dari cetakan dan membentuk barang jadi (karet kopling).

Selanjutnya karet kopling dilakukan pengujian swelling dan ketahanan using. Uji swelling dengan cara direndam dalam oli mesin motor SAE $10 \mathrm{~W}$ - 40 pada suhu perendaman bervariasi $25^{\circ} \mathrm{C}$ dan $100^{\circ} \mathrm{C}$. Lama perendamam bervariasi, yaitu, 24 jam, 48 jam, 72 jam, 96 jam dan 120 jam dan uji ketahanan usang dilakukan dengan cara pengusangan selama 24 jam pada suhu $70 \pm 5^{\circ} \mathrm{C}$.

\section{Peubah yang Diamati}

Peubah yang diamati meliputi perubahan volume (volume pengembangan/swelling) karet kopling dan ketahanan usang karet.

\section{HASIL DAN PEMBAHASAN}

\section{Swelling}

Uji swelling dilakukan untuk mengetahui persentase penambahan berat sampel uji karet kopling kendaraan bermotor setelah direndam oli mesin motor SAE 
10W - 40 dengan waktu tertentu. Hasil dari uji swelling karet kopling kendaraan bermotor diperlihatkan pada Gambar 1 dan 2.

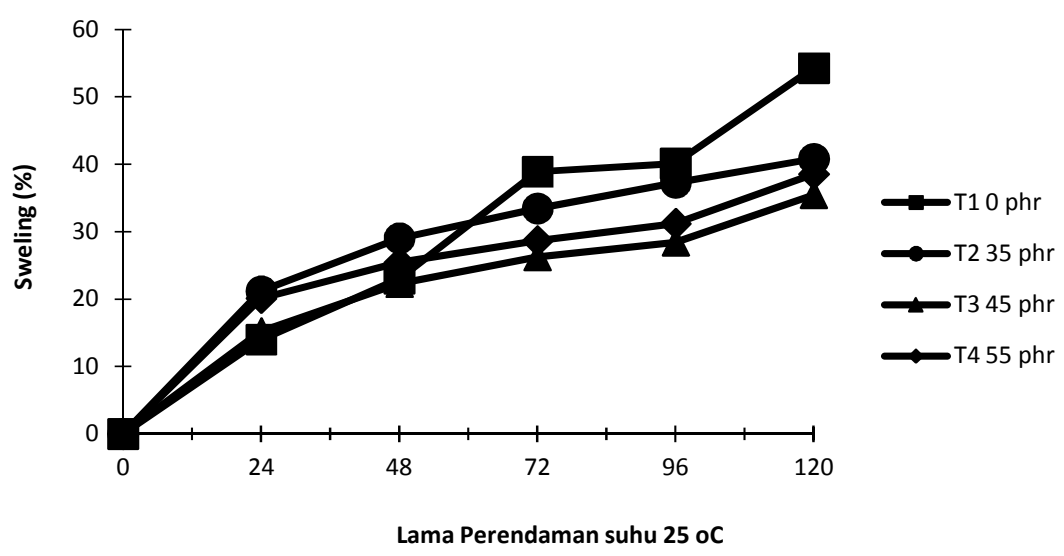

Gambar 1. Hasil dari uji swelling karet kopling lama perendaman $25^{\circ} \mathrm{C}$.

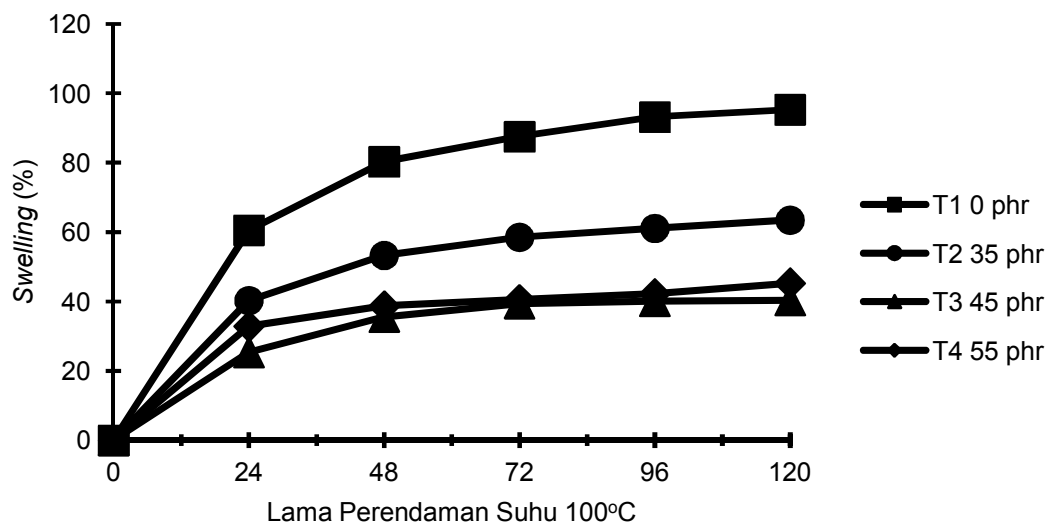

Gambar 2. Hasil dari uji swelling karet kopling lama perendaman $100^{\circ} \mathrm{C}$.

Berdasarkan Gambar 1 dan 2, terlihat TKKS menghasilkan persentase swelling bahwa semakin tinggi konsentrasi arang yang semakin kecil, hal ini disebabkan arang TKKS dan semakin lama waktu perendaman TKKS akan membatasi laju swelling. Selain karet kopling, persentase swelling semakin itu, rapat ikatan silang juga berpengaruh besar kecil. Vulkanisat karet kopling tanpa bahan terhadap persentase swelling, dimana pengisi $(\mathrm{T} 1=0 \mathrm{phr})$ memiliki persentase persentase swelling akan semakin menurun perubahan volume tertinggi, diikuti dengan seiring dengan peningkatan rapat ikatan silang konsentrasi bahan pengisi TKKS T2 $=35 \mathrm{phr}$ (Ramadhan dan Irfan, 2013). Dengan hingga T4 = 55 dan mencapai optimum pada demikian, dari hasil uji swelling menunjukkan konsentrasi arang TKKS T3 $=45 \mathrm{phr}$. Adanya bahwa penambahan arang TKKS yang lebih bahan pengisi TKKS membatasi difusi pelarut banyak dapat mengurangi ikatan silang yang ke dalam polimer karet, sehingga terbentuk antara molekul karet dengan pengembangan volume kecil. Bahan pengisi molekul belerang.

akan mencegah difusi pelarut ke dalam volume bebas antar molekul (Abdul dan Bhowmick, 2003; Ramesan, 2005). Lamanya waktu perendaman vulkanisat karet dengan semakin meningkatnya konsentrasi arang

Gambar 2 terlihat bahwa hasil uji swelling vulkanisat karet dengan cenderung memiliki persentase swelling lebih besar dibandingkan dengan hasil uji swelling Gambar 1 dengan suhu perendamanan $25^{\circ} \mathrm{C}$, 
sebagian besar elastomer memiliki kinerja cukup baik pada suhu rendah. Minyak pada suhu rendah masih berbentuk kental dan koefisien difusi yang kecil, yang menyebabkan swelling cukup rendah. Pada suhu rendah, difusi sangat rendah dan lambat dan elastomer kurang fleksibel, yang membatasi kinerja vulkanisat karet, sehingga perubahan volume vulkanisat karet akan menjadi lambat. Selain itu terjadinya swelling elastomer karena difusi fraksi minyak yang lebih tinggi ke dalam elastomer (Zielińska et al., 2016; Seyger et al., 2013).

Peningkatan suhu perendaman vulkanisat karet dalam pelarut minyak, akan meningkatkan swelling (Petrova et al., 2005). Pada suhu yang lebih tinggi, keseimbangan tercapai lebih awal dari pada suhu kamar. Kecepatan penyerapan pelarut meningkat dengan naiknya suhu. Ini dapat dijelaskan dengan pergerakan molekul yang lebih cepat di antara rantai elastomer pada suhu yang lebih tinggi yang mempercepat proses swelling, karena peningkatan koefisien difusi. Suhu yang tinggi juga mengurangi kekuatan elastomer, hal ini menyebabkan perubahan dimensi dan penurunan sifat fisik. Ikatan silang yang terbentuk pada proses vulkanisasi akan membatasi ekspansi senyawa karet yang menyulitkan pelarut untuk berdifusi ke dalam celah antar molekul, sehingga mengurangi rasio swelling (Phanny et al., 2013). Semakin tinggi rapat ikatan silang akan meningkatkan kekerasan dan kekuatan tarik, mengurangi perpanjangan putus dan kompresi, dan meningkatkan ketahanan terhadap pelarut (Kinasih and Fathurrohman, 2017). Perlakuan terbaik diperoleh pada T3 $45 \mathrm{phr}$, memberikan nilai swelling terkecil (suhu perendaman dalam pelarut minyak $25^{\circ} \mathrm{C}$, yaitu $15,22 \%$ hingga $35,5 \%$ dan suhu perendamanan $100^{\circ} \mathrm{C}$, yaitu $25,35 \%$ hingga $40,35 \%)$.

\section{Ketahanan Usang}

Pengusangan merupakan fenomena umum yang terjadi pada elastomer alami dan sintetik berupa penurunan sifat yang tidak diinginkan selama penyimpanan ataupun penggunaan. Berbagai perubahan dapat terjadi pada suatu komponen elastomer sebagai hasil dari kondisi dimana elastomer tersebut disimpan atau digunakan. Ketahanan vulkanisat karet terhadap pengusangan dianggap sebagai persyaratan penting untuk kinerja produk yang lebih baik.

\section{Kekerasan}

Kekerasan diukur untuk menentukan tingkat vulkanisasi produk karet, dan mewakili elastisitas produk karet. Nilai kekerasan kompon karet semakin tinggi menunjukkan bahwa vulkanisat karet semakin keras (semakin tidak elastis). Hasil pengujian kekerasan vulknisat karet terendah sebelum dan sesudah pengusangan diperoleh pada perlakuan $\mathrm{T} 1=0 \mathrm{phr}$, yaitu 48 Shore $A$ dan 56 Shore A. Hasil pengujian tertinggi sebelum pengusangan diperoleh pada perlakuan T4 $=55 \mathrm{phr}$, yaitu 67 Shore A dan 72 Shore A. Hasil pengujian kekerasan vulknisat karet tertinggi setelah pengusangan diperoleh pada perlakuan $\mathrm{T} 3=35 \mathrm{phr}$, yaitu 70 Shore A. Hasil pengujian kekerasan vulkanisat karet kopling kendaraan bermotor semua perlakuan seperti disajikan pada Gambar 3.

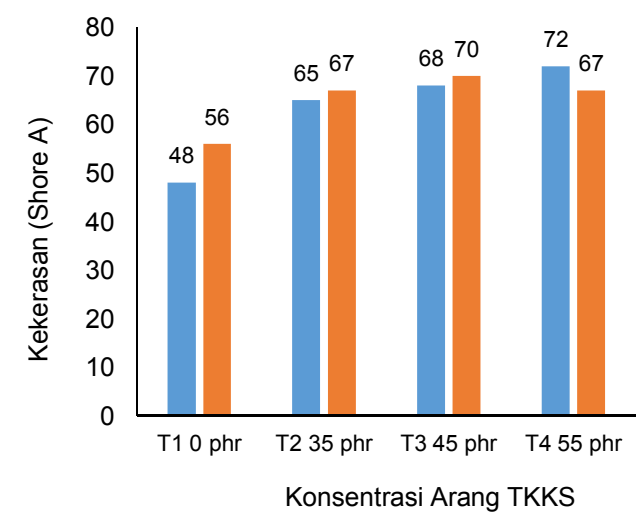

-Sebelum pengusangan $\backsim$ Setelah Pengusangan

Gambar 3.Kekerasan karet kopling kendaraan bermotor roda dua

Hasil uji kekerasan Gambar 3, menunjukkan bahwa kekerasan vulkanisat sesudah pengusangan meningkat dengan bertambahnya konsentrasi arang TKKS. Meningkatnya 
kekerasan disebabkan oleh peningkatan densitas ikatan silang dari campuran. Fleksibilitas dan elastisitas rantai karet lebih sedikit ketika bahan pengisi dimasukkan ke dalam karet alam, yang juga menghasilkan vulkanisat karet yang lebih kaku dan peningkatan kekerasan karena adanya ikatan silang yang terbentuk dengan adanya bahan pengisi (Ismail et al., 2015; Rattonsom et al., 2005).

Selain itu, perubahan kekerasan kompon karet disebabkan terjadinya oksidasi secara umum, semakin besar jumlah ikatan jenuh dalam polimer karet, semakin rentan degradasi. Polimer karet tak jenuh tinggi dapat bereaksi dengan oksigen, terutama ketika adanya energi. Energi dapat berasal dari panas, pergeseran, dan sinar ultraviolet (UV), yang menyebabkan lebih cepat terjadinya oksidasi. Peningkatan nilai kekerasan vulkanisat karet kopling kendaraan bermotor setelah pengusangan tidak signifikan dibandingkan dengan kekerasan sebelum pengusangan. Perlakuan yang memenuhi standar mutu karet kopling kendaraan bermotor komersil, yaitu perlakuan T2 $=35 \mathrm{phr}$ hingga perlakuan T4 $=55$ phr. Standar mutu karet kopling komersil untuk kekerasan yaitu $70 \pm 5$ phr.

\section{Tegangan Putus}

Tegangan putus diartikan sebagai sumber kekuatan yang digunakan untuk memutuskan sampel sampai putus (Marlina, 2016). Tegangan putus digunakan untuk menunjukkan kemampuan karet bereaksi terhadap gaya yang digunakan pada saat di tekan. Pada dasarnya karet alam memiliki tegangan putus yang baik karena kemampuannya mengkristal pada saat mengalami perpanjangan karena adanya gaya tarik. Tegangan putus karet kopling kendaraan bermotor roda dua disajikan pada Gambar 4.

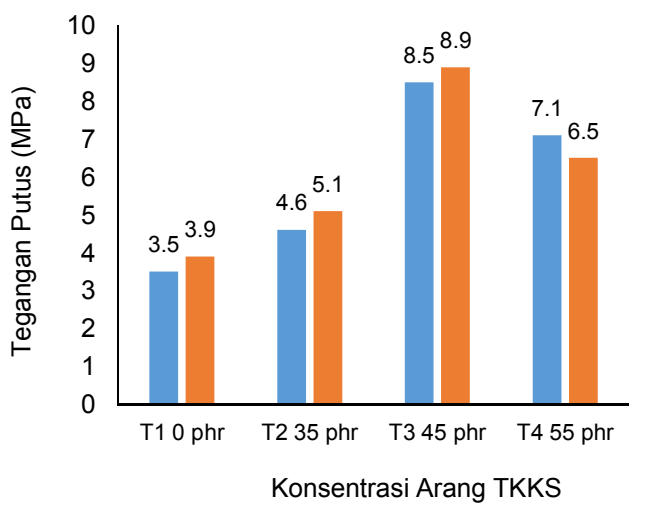

- Sebelum Pengusangan "Setelah Pengusangan

Gambar 4. Tegangan putus karet kopling kendaraan bermotor roda dua

Berdasarkan Gambar 4, Hasil pengujian tegangan putus vulknisat karet kopling terendah sebelum dan sesudah pengusangan diperoleh pada perlakuan $\mathrm{T} 1$ = $0 \mathrm{phr}$, yaitu 3,5 $\mathrm{MPa}$ dan 3,9 MPa. Hasil pengujian tertinggi sebelum dan sesudah pengusangan diperoleh pada perlakuan $\mathrm{T} 3=45 \mathrm{phr}$, yaitu $8,5 \mathrm{MPa}$ dan 8,9 MPa. Semakin tinggi konsentrasi arang TKKS semakin besar nilai tegangan putus vulkanisat kopling dan mencapai optimum pada perlakuan $\mathrm{T} 3=35$ phr. Efektivitas bahan pengisi dapat diukur dengan kandungan karbonnya. Bahan pengisi dengan kandungan karbon lebih tinggi, memberikan penguatan lebih besar dari pada yang memiliki kandungan karbon lebih rendah karena karbon itu sendiri adalah pengisi penguat yang sangat baik. Selain itu tegangan putus dipengaruhi oleh ukuran partikel pengisi, luas permukaan pengisi dan geometri pengisi (Mishra dan Shimpi, 2005). Ukuran partikel bahan pengisi mempengaruhi karakteristik tegangan putus vulkanisat karet. Semakin kecil ukuran partikel bahan pengisi maka luas permukaan akan semakin besar, sehingga meningkatkan luas permukaan interface (antar muka) karet dengan bahan pengisi. Interaksi antarmuka yang baik menyebabkan pengisi lebih mudah terdispersi di dalam karet alam. Hal ini menyebabkan vulkanisat karet dapat mentransfer panas dengan baik 
dan mengurangi efek penurunan sifat akibat pengusangan. Karet alam merupakan polimer yang terdiri dari unit monomer isoprene $\left(\mathrm{C}_{5} \mathrm{H}_{8}\right)$ dengan satu ikatan rangkap tiap monomernya. Adanya ikatan rangkap dan gugus metilen merupakan gugus reaktif untuk terjadinya ikatan kimia (Donnet and Custedero, 2005). Terbentuknya ikatanikatan mengakibatkan karet menjadi kaku dan kuat sehingga tegangan putusnya tetap tinggi setelah pengusangan. Tegangan putus juga dipengaruhi oleh jumlah antioksidan yang digunakan, hal ini sesuai pendapat Klyosov (2007), yang menyatakan jumlah antioksidan yang cukup banyak dapat meningkatkan tegangan putus material, sementara Chong et al., (2010), melakukan penelitian menggunakan antioksidan sebanyak 1,5 phr. Menurut Honggokusumo (2015), antioksidan yang ditambahkan dalam pembuatan kompon karet maksimal 2 phr. Perlakuan yang memenuhi standar mutu sesuai karet kopling komersil (tegangan putus minimal $4 \mathrm{MPa}$ ), didapat pada perlakuan $\mathrm{T} 2=35 \mathrm{phr}$ hingga $\mathrm{T} 4=55 \mathrm{phr}$.

\section{Perpanjangan Putus}

Perpanjangan putus menunjukkan adanya keuletan, elastisitas atau fleksibilitas bahan karena pengaruh peregangan (stretching) sampai putus (Nabil et al., 2013). Nilai perpanjangan putus karet kopling kendaraan bermotor roda dua terendah sebelum dan sesudah pengusangan diperoleh pada perlakuan T1 = 0 phr, yaitu $260 \%$ dan $205 \%$. Nilai perpanjangan putus tertinggi sebelum dan sesudah pengusangan pada perlakuan T3 $=45 \mathrm{phr}$, yaitu $420 \%$ dan $411 \%$. Pepanjangan putus karet kopling kendaraan bermotor roda dua disajikan pada Gambar 5.

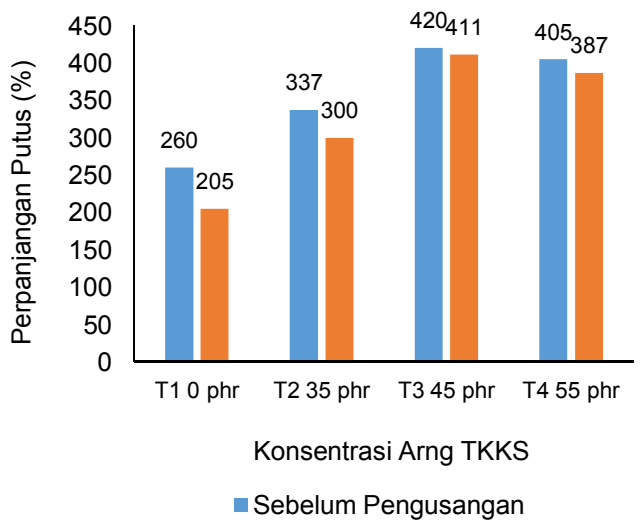

Gambar 5 Perpanjangan putus karet kopling kendaraan bermotor roda dua

Hasil uji perpanjangan putus Gambar 5, menunjukkan semakin tinggi konsentrasi arang TKKS yang ditambahkan pada pembuatan karet kopling kendaraan bermotor setelah pengusangan, nilai perpanjangan putus semakin menurun dan mencapai konsentrasi optimum pada 45 phr. Penurunan perpanjangan putus setelah pengusangan disebabkan berkurangnya penguraian dan terlepasnya rantai karet, sehingga jumlah ikatan rangkap menurun akibatnya terjadi kekakuan matriks karet. Penurunan perpanjangan putus juga dapat disebabkan meningkatnya rapat ikatan silang antar molekul karet. Selain itu, makin banyak bahan pengisi yang ditambahkan, perpanjangan putus turun karena dimungkinkan terjadinya aglomerasi agregat akibat tidak semua arang TKKS dapat berikatan dengan molekul karet. Keadaan tersebut disebabkan karena jenuhnya molekul karet sehingga vulkanisat ditarik akan mudah putus. peningkatan kekakuan dan kerapuhan, yang menurunkan ketahanan terhadap peregangan kompon karet. Penurunan perpanjangan putus dapat disebabkan meningkatnya rapat ikatan silang antar molekul karet. Meningkatnya rapat ikatan silang molekul karet karena adanya kandungan sulfur bebas yang menyebabkan ikatan silang lebih lanjut selama proses pengusangan. Semakin lama waktu pengusangan rapat ikatan silang akan semakin menurun, hal 
ini disebabkan adanya dekomposisi silang molekul karet. Pembentukan ikatan silang baru terjadi dalam vulkanisat yang mengalami pemasakan yang tidak sempurna, yang memiliki kandungan sulfur bebas.

Banyaknya ikatan yang terbentuk akan mengurangi keleluasaan gerak rantai polimer, menyebabkan viskositas kompon meningkat, kompon menjadi kaku, keras dan elastisitasnya turun (Phrommedetch dan Pattamaprom, 2010).

Nilai perpanjangan putus vulkanisat kopling pada perlakuan $\mathrm{T} 2=35 \mathrm{phr}$ hingga $\mathrm{T} 4=55 \mathrm{phr}$ dengan nilai perpanjangan putus $300 \%$ hingga $420 \%$ memenuhi syarat mutu vulkanisat kopling kendaraan bermotor komersil, yaitu minimal $300 \%$.

\section{KESIMPULAN}

Penggunaan arang TKKS dengan berbagai konsentrasi $(\mathrm{T} 1=0 \mathrm{phr}, \mathrm{T} 2=$ $35 \mathrm{phr}, \mathrm{T} 3=45 \mathrm{phr}$ dan $\mathrm{T} 4=55 \mathrm{phr}$ ), berpengaruh terhadap swelling dan ketahanan usang karet kopling kendaraan bermotor roda dua. Semakin tinggi konsentrasi arang TKKS yang ditambahkan dalam pembuatan karet kopling kendaraan bermotor roda dua nilai swelling semakin kecil. Ketahanan usang karet kopling untuk kekerasan, tegangan putus dan perpanjangan putus memenuhi persyaratan teknis karet kopling komersil.

\section{UCAPAN TERIMA KASIH}

Penulis mengucapkan terima kasih kepada Bapak Bambang Sugiyono, Ibu Mimi Kurnia Yusha dan Rori Andhika atas bantuannya dalam melakukan kegiatan praktek lapangan, dan pengujian di laboratorium hingga terselesaikannya penelitian ini.

\section{DAFTAR PUSTAKA}

Abdul Kader, M, Bhowmick, A.K. (2003). Acrylic rubber-fluorocarbon rubber miscible blends: Effect of curatives and fillers on cure, mechanical, aging, and swelling properties.
Journal Applied Polymer of Science. 89 : 1442-1452.

Al-Rahman, Z. L. A, Raja, R. I., Rahman, R. A., Ibrahim. (2014). Comparison of acoustic characteristics of date palm fibre and oil palm fibre. Research Journal of Applied Sciences, Engineering and Technology. Pp : 1656-1661.

Chong, E.L., Ahmad, I., Dahlan, H.M dan Abdullah, I. (2010). Reinforcement of Natural Rubber/High Density Polyethylene Blends with Electron Beam Irradiated Liquid Natural Rubber-Coated Rice Husk. Radiation Physics and Chemistry. 79 (8) : 906-911.

Daud, S., Ismail, H., dan Bakar, A.A. (2016). The Effect of 3aminopropyltrimethyoxysilane (AMEO) as a Coupling Agent on Curing and Mechanical Properties of Natural Rubber/Palm Kernel Shell Powder Composites. Procedia Chemistry. 19: 327 334.

Donnet, J.B., Custedero, E. (2005). Science and technology of rubber : reinforcement of elastomers by particulate fillers. Elsevier Academic Press Third Edition $P: 367-400$.

Honggokusumo, S. (2015). Desain Kompon. Fundamental of Rubber Technology (Product Design, Compounding, Processing and Testing). Disampaikan pada Technical Training, tanggal 24-26 Februari 2015.

Ismail, A. M. A. L. Ghazali, M. I., Mahzan, S., and Zaidi. (2010). Sound Absorption of Arenga Pinnata Natural Fiber. World Academy Science Engineering and Technology. Pp : 601-603.

Ismail. H, Syaza, H. A and Azura A. R. (2015). Fatigue, Resilience, Hardness, and Swelling Behaviour of Natural Rubber/Recycled Acrylonitrile-Butadiene Rubber (NR/NBRr) Blends. Polymers \& Polymer Composites. 23 (8) : 583 $-588$. 
Kinasih. N.A, and Fathurrohman, M.I. (2017). Effect of curing systems on mechanical properties and npentane resistance of carbon black filled natural rubber vulcanizates. Journal of Engineering and Science Research 1 (2): 245-251.

Klyosov, A.A. (2007). Plastic Composites, John Wiley \& Sons, New York, NY, USA.

Marlina, P, Pratama, F, Hamzah, B and Pambayun, R. (2014). Pengaruh suhu dan lama penyimpanan terhadap karakteristik kompon karet dengan bahan pengisi arang aktif tempurung kelapa dan nano silika sekam padi. Jurnal Dinamika Penelitian Industri. 25 (1) : $43-51$.

Marlina, P. (2016). Karakteristik Vulkanisat Lis Kaca Kendaraan Bermotor Setelah Pengusangan. Prosiding Seminar Nasional Kulit Karet Plastik ke-5,tanggal 26 Oktober 2016. Yogyakarta. pp : 61 -70 .

Mishra. S and Shimpi. NG. (2005). Mechanical properties of flameretardant properties of styrenebutadiene rubber filled with $\mathrm{CaCO} 3$ as a filler and Linseed oil as an extender, Journal of Applied Polymer Science, 98(6) : 25632571.

Nabil, H., Ismail, H., \& Azura, A. R. (2013). Compounding, mechanical and morphological properties of carbon-black-filled natural rubber/recycled ethylenepropylene-diene-monomer (NR/REPDM) blends. Polymer Testing, 32(2) : 385-393.

Osabohien, E., dan Egboh, S.H.O. (2007). Cure characteristics and physico-mechanical properties of natural rubber filled with the seed shells of cherry (Chrysophyllum albidum). Journal of Applied Science Environment Management. 11(2) : $43-48$.

Petrova N.N., Popova A.F. and Startsev O.B. (2005). Peculiarities of rubber-oil interaction under the conditions of cold climate. Progress in Chemometrics Research. 18 : 265-271.

Phanny,Y., A.R. Azura and H.Ismail. (2013). Effect of Different Origins of Natural Rubber on The Properties of Carbon Black Filled Natural Rubber Composites. ASEAN Engineering Journal, 2 (1): 68-75.

Prasetya, H. (2017). Local natural resources filler in making of radiator cap seal vulcanized. Jurnal Dinamika Penelitian Industri. 28 (2) : 131 - 137.

Phrommedetch, S and Pattamaprom, C. (2010). Compatibility Improvement of Rice Husk and Bagasse Ashes with Natural Rubber by MoltenState Maleation. European Journal of Scientific Research . 43 (3) : 411-416.

Ramadhan. A dan Irfan. F.A. (2013). Pengaruh asam stearat terhadap Karakteristik pematangan, sifat mekanik dan swelling vulkanisat karet alam dengan bahan pengisi organoclay. Jurnal Sains Materi Indonesia. 14 (2) : 108-113.

Ramesan, M.T. (2005). The effects of filler content on cure and mechanical properties of dichlorocarbene modified styrene butadiene rubber/carbon black composites. Journal Polymer of Ressonance. $11:$ 333-340.

Rattanasom N., Poonsuk A. and Makmoon T. (2005). Effect of curing system on the mechanical properties and heat aging resistance of natural rubber/tire tread reclaimed rubber blends. Polymer Testing. 24 : 728-732.

Seyger. R, Resink. S, Harms. $\mathrm{H}$ and Hibberd. R. (2013). The Future of Swelling Elastomers: An Elastomer Manufacturer's View of Swelling Elastomer Developments and Market Trends. The Journal of Engineering Research. 10 (1) : 50-64.

Shinoj, S. P. S, Kochubabu, M, Visvanathan,R. (2011). Oil palm fiber (OPF) and its composites: 
A review. Industrial Crops and Products. 33:7-22.

Sung, Giwook dan Jung Hyeun Kim. (2017). Infulence of filler surface characteristics on morphological, physical, acoustic properties of polyurethane composite foams filled with inorganic fillers. Composites Science and Technology. 146 : 147-154.

Vichitcholchai N., Na-ronang N., Noisuwan W and Arayapranee W. (2012). Using rice husk ash as filler in rubber industry. Rubber Thai Journal. 1 : 48-55.

Vijayan, S.N, Makeshkumar, M, and Sridhar, K. (2012). Physical and chemical analysis of activated carbon prepared from coconut shell charcoal and usage-acase study. International Journal Advantage Science Resourches and Technology, $3:$ 16-175.

Zielińska. M, Seyger. R, Wilma K. D, Bielinski D and Noordermeer J.W.M. (2016). Swelling of EPDM rubbers for oil-well applications as influenced by medium composition and temperature Part I. Literature and theoretical background. Elastomery. 20 (2) : 6 -17. 